\title{
Knowledge of Female Prisoners in a City of Ceará, Brazil, about Sexually Transmitted Diseases
}

\author{
Cinthia Gondim Pereira Calou1,2, Camila Fonseca Wasidi², \\ Maria de Fátima Esmeraldo Ramos de Figueiredo² ${ }^{2}$ Ana Izabel Oliveira Nicolau1, \\ Ana Karina Bezerra Pinheiroㅁ, Régia Christina Moura Barbosa Castro, \\ Priscila de Souza Aquino ${ }^{1}$ \\ ${ }^{1}$ Universidade Federal do Ceará, Fortaleza, Brazil \\ ${ }^{2}$ Universidade Regional do Cariri, Crato, Brazil \\ Email: cinthiacalou@hotmail.com
}

Received 2 July 2014; revised 27 July 2014; accepted 5 August 2014

Copyright (C) 2014 by authors and Scientific Research Publishing Inc. This work is licensed under the Creative Commons Attribution International License (CC BY). http://creativecommons.org/licenses/by/4.0/

c) (i) Open Access

\begin{abstract}
Exploratory study was conducted in the Crato Public Prison, State of Ceará, Brazil, aiming to understand the knowledge and experiences related to the preventive aspects of Sexually Transmitted Diseases (STDs) in the prison context. The target population of the study consisted of 14 female inmates, 10 of whom agreed to participate. Data collection occurred in June 2012 through recorded semi-structured individual interviews. We investigated quantitative, socio-demographic and sexual variables. In qualitative data analysis, we applied the Meaning Interpretation Method. The female vulnerability was aggravated by the early onset of sexual activity, lack of knowledge about STDs, non-adoption of preventive measures and history of prostitution. The following categories emerged from the qualitative assessment: Knowledge about STD/AIDS versus Personal Experience; Use of contraception as STD/AIDS prevention within the Public Jail; Habits of inmates: alcohol and tobacco; and Characterization of the conjugal visit area.
\end{abstract}

\section{Keywords}

Prisoners, Nursing, Women's Health, Sexual and Reproductive Health

\section{Introduction}

Human rights are fundamental rights designed for every single person, even while concerning the protection and 
guarantee of physical integrity of human beings. From this premise, we notice that women deprived of their freedom require conditions to serve their sentence with a minimum of dignity.

Given the importance of health care in this specific group, the Ministries of Justice and Health established the National Health Plan in the Prison System (PNSSP), which provided for the organization of the effective access of inmates in male, female and psychiatric units to actions and services of the Unified Health System (SUS). Primary care services should be organized in the very prison unit, through the assistance provided by multidisciplinary teams, and the other levels should be referenced [1].

According to data from the National Penitentiary Department (DEPEN), the incarceration rate of women from 2000 to 2006 increased by 135.37\%, much higher than those of men, which grew by 53.36\%. In the Northeast Region of Brazil, from 2002 to 2005, the female prison population increased by 23.1\% [2]. Such fact highlights the need for greater investments in public policies targeted at this population, assuring their rights through interdisciplinary health teams that provide comprehensive health care and organized within the correctional facility [2].

Estimates from the Joint United Nations Programme on HIV/AIDS (UNAIDS) show that the growing number of incarcerated women is followed by elevated prevalence of Sexually Transmitted Diseases (STDs)/AIDS, which is higher among prison inmates than in general population. The conditions of confinement, invisibility of this population segment, poor physical facilities, violence, prison overcrowding, poor access to information and prevention materials (condoms), inadequate care and lack of prospects are factors that aggravate the vulnerability of these people to STD/HIV/AIDS [3].

Therefore, it is essential to intensify the attention to health promotion of incarcerated women, not only for the existing risks in the prison environment, but also for the lack of preventive measures offered within the prison health system. Given this educational approach, we highlight the nurse, for being an essentially professional caregiver and educator. For this reason, the nurse professional must take over health education, even as a member of the health team of the prison system, acting as a facilitator of the educational process, beyond the traditional information transfer and stimulating the individual to reflect and adopt healthy habits.

Given the influence of information and awareness of the importance of taking preventive measures in health, transformation and development of personal skills for the achievement of health promotion, we aim at understanding the knowledge and experiences related to STD prevention in the prison context.

This assessment will provide information for the development of future policies and educational strategies that support different approaches to STD/AIDS, consistent with the singularities of the group in question. Additionally, we believe that the applicability of the study will contribute to strengthening the nursing care to this vulnerable clientele, with strong need of a closer care, hence making the nurse performance increasingly universal and holistic.

In order to truly understand the prison situation experienced by the study participants, we chose as theoretical framework the Meaning Interpretation Method, which intends to interpret the context, the reasons, and the individual and social logics from the reports collected. It is a current of analysis of several aspects related to the study population, such as words, actions, inter-relationships, groups, among others. We can even say that the method is grounded in the perspective of hermeneutics and dialectics, the first means understanding, interpreting the meaning of the text, while the second represents the critical thinking [4].

The Meaning Interpretation Method seeks to advance on observation beyond what was covered in the text, directing to its whole and seeking to explain the attitude of a particular culture about a subject [5], thus the importance of comparing ideas. For data interpretation, we need to look for the logic of facts, beyond what was described and observed, be in the context of individuals and report the facts so that those are recognized in context.

\section{Method}

The study had a qualitative approach exploring the participant's experiences through interviews.

The research took place at the Crato Public Prison, in the State of Ceará, Brazil. The prison has 8 cells, with 7 for male inmates and 1 for females, and an average capacity of 20 inmates per cell. Despite being a small prison, some of the convicted prisoners serve time along with temporary prisoners, thus requiring the application of the PNSSP.

The study population was composed by the female inmates of the county jail. There were 14 inmates on the day of the interview, 10 of whom agreed to participate in the research, thus composing the number of study sub- 
jects. Data collection occurred in June 2012 through recorded semi-structured individual interviews conducted in the study room of the prison, where the inmates have more privacy. The interview provides both documentary data and information from the individual's reflections about their real experiences [6].

Initially, we present some quantitative variables related to age of first sexual intercourse, type of STD known, knowledge about STD preventive measures, history of prostitution, conjugal visits and information/assistance on STD through table containing the absolute and relative frequencies.

In qualitative data analysis, we divided the interpretation into the following steps: comprehensive reading of the material, transcript of the tape recording, exploration and development of interpretive synthesis. The text was divided into meaning units that were condensed, summarized, and labeled with a code to reflect the content. The codes were then compared and, depending on content, organized into sub-themes that were summarized and merged into themes [5] [7].

The four categories formulated were: Knowledge about STD/AIDS x Personal Experience; Use of contraception as STD/AIDS prevention within the Public Jail; Habits of inmates: alcohol and tobacco; and Characterization of the conjugal visits area.

To ensure the anonymity of the subjects, the ten inmates were named after flowers: Rose, Petunia, Daisy, Violet, Azalea, Lily, Orchid, Hydrangea, Tulip and Jasmine. It is important mentioning that the ethical aspects of research involving human beings in accordance with the recommendations of Resolution 466/2012 of the National Health Council of Brazil were respected [8]. This study is part of a project entitled "STDs in women of childbearing age" approved by the Research Ethics Committee of the Universidade Regional do Cariri (URCA) under protocol number 42.054/2010-08.

\section{Results}

The study results were presented according to the characterization of participants and thematic analysis.

\subsection{Characterization of Participants}

Given the age of first sexual intercourse, we were able to identify the early sexual debut, since 6 participants initiated before the age of 14, and overall, 8 had their first sexual intercourse in adolescence.

When asked about the types of STDs they knew, HIV/AIDS represented the most known pathology, with a notorious weakness regarding information to numerous STDs. Eight of the ten inmates knew some preventive method, one of these mentioned that used intimate hygiene as prevention, instead of condoms.

It is worth mentioning that less than half of them, 4 women, used condoms, in other words, despite knowing how to prevent STDs, most do not practice safe sex. We found that half of the inmates experienced some situation of prostitution, being vulnerable to risks that can be intensified for STDs.

Regarding conjugal visits, most women, 7, were benefited by the fact their partners are inmates at the same prison, unlike the other whose partners were not prisoners. The evaluation of preventive actions regarding STD developed within the correctional facility showed that almost all, 9, claimed to have never received information about this topic.

\subsection{Thematic Analysis}

Given the presentation and discussion of the abovementioned data, the next step concerns the knowledge on issues related to STD/AIDS, which led to discussion with the inmates through four categories: Knowledge about STD/AIDS x Personal Experience; Use of contraception as STD/AIDS prevention within the Public Jail; Habits of inmates: alcohol and tobacco; and Characterization of the conjugal visits area.

\subsubsection{First Axis: Knowledge about STD/AIDS x Personal Experience}

Through the speeches, we notice a lack of content on the concept, transmission, prevention, diagnosis and the types of STD/AIDS. These statements help identifying the gap between knowledge and information delivered, ultimately contributing to an anachronism in the educational process on the prevention of STDs: I do not know. I know that I never had it, I have seen some people talk on television, but I am not sure what it is. (Rosa) I know gonorrhea, discharge, these things [...]. I do have, slightly yellow and itches a little. (Azalea) HIV, gonorrhea [...]. I have a lump for more than a year. I have a yellowish green discharge. (Lily) I know, Sexually Transmitted 
Diseases. I learned about these STDs when I worked as a waitress at a bar, there were some people from the health department, and also from school. (Orchid).

\subsubsection{Second Axis: Use of Contraception as STD/AIDS Prevention within the Public Jail}

The statements below evidenced that most respondents did not use condoms, reporting different reasons: because the husband does not accept it, for they have used it for a long time, for they use oral contraceptive aimed only at avoiding unwanted pregnancy, or even due to the lack of knowledge that this does not prevent STD/AIDS. Others claim to use it, however, they present vaginal discharge with characteristics of infection: No, I have never used condom. (Rosa) They give it, now there is a pill, I do not even know for what it is, and women are taking it, is the 121. I do not take it [...] (Petunia) I take the pills that you must take one each day. I do not use condoms. (Daisy) I use 21-day cycle and condom [...] (Azalea) I do not use anything. My partner does not want to use it, he says it restrains and he wants to have a child [...] (Lily). I have used a lot of condoms and the pill, but today I do not use them anymore. (Orchid)

\subsubsection{Third Axis: Habits of Female Inmates Related to Alcohol, Tobacco and Other Drugs}

In the perspective of all inmates, vices acquired through the consumption of tobacco and alcohol were justified by the idleness inside the prison, represented to them as an opportunity to escape from their own reality, to "alleviate" the suffering experienced, however, they end up becoming addicted and committing crimes: Here inside, I smoke circa a pack, 20 cigarettes. I have spent three years without smoking then started again. (Petunia). I smoke. I drink. Oh! A pack. I have never tried to stop (Daisy). I drink. I smoke. I smoke so much that I do not even count how many there are. I think it is more than two, around three. (Hydrangea).

\subsubsection{Forth Axis: Characterization of the Conjugal Visits Area}

The description of this theme, by incarcerated women, portrays the violation of human rights. According to the participants, the intimate visits take place on Sundays, without a place with proper hygiene conditions for its realization. The sexual encounter happens in their own cell with mattresses borrowed from other inmates, privacy happens through sheets used to cover while the couples meet, with several couples together in the same cell.

The employee who makes the search on prisoners and visitors also distributes condoms; however, some people do not use them, reporting there is no instructions on its use and importance. It happens like this, who is in the room comes here, then, there is one at a time. (Daisy) It is in a cell, we share it, right?! Then, they cover it with bed sheets. Nobody sees it, is intimate. There are several couples [...] on Sunday the woman gives me a condom. Sometimes I use it. (Orchid). My husband comes, there always a place, borrowed, but there is. (Hydrangea).

\section{Discussion}

The analysis of socio-demographic information revealed a reality experienced by young women, single, with low education, unemployed and imprisoned due to drug trafficking. This is the situation of many young Brazilians, demonstrating the need to strengthen policies and programs aimed at children and young people in the country, so that poverty, professional unpreparedness, unfavorable environment and lack of prospects do not become the main motivators of crime in Brazil [9].

In this study, we found the association between the lack of knowledge of inmates about STD/AIDS and its implications on the attitudes experienced by women in prison, making them more vulnerable to risky behaviors.

Early sexual initiation indicates that family planning strategies and promotion of sexual and reproductive health should include adolescence intensively, once this can be essential in resolving the gynecologic and obstetric history of these youth. However, misinformation, asymptomatic presentations and difficult access to health services prior to imprisonment, as well as during it, favor the non-identification of these diseases among the population and the underestimation of these occurrences, as revealed by the incarcerated women. Given its magnitude, transcendence, vulnerability to actions and feasibility of control, Sexually Transmitted Diseases (STDs) should be prioritized.

STDs are one of the most common public health problems worldwide. Among its consequences are infertility, vertical transmission and increased risk for HIV infection. They are usually preventable and treatable, with the exception of diseases caused by viruses. Even though condom is the most effective method to reduce the risk for 
STDs, its rates of use are still very low. This mostly occurs by factors such as steady relationship, trusting the partner, lack of promiscuous relations, and use of another contraceptive method [10].

Information involving health-related issues is extremely important and should be taken into consideration, especially for this population, being more widespread within prisons, in order to encourage a healthy behavior, hence preventing sexually transmitted diseases.

Contradicting the recommended by the National Health Plan in the Prison System, the female inmates are not covered with permanent services for clarification on health issues, strengthening risk situations for acquiring STDs.

The prison population, being confined and accessible, should represent a share with a better approach by health professionals in targeting programmatic actions to prevent STD/HIV grounded on the peculiarities experienced in the prison system. In this sense, imprisonment can constitute an opportunity for care, mainly because many of these women have never sought health care prior to incarceration [11].

In this context, health professionals should act as educators, widening their view beyond the biological aspects, considering also the socio-cultural issues surrounding this vulnerable population, which often determine the decision-making, not always consistent to maintain a state that promotes healthy habits for life.

The fact the individual has knowledge and positive attitudes facilitates the adoption of preventive behaviors, but does not ensure it, especially if there is support and appropriate conditions that favor this behavior change and maintenance of practice [12].

The participants of the study presented poor knowledge about male condoms, reflecting the ineffectiveness of the guidelines conducted. If most women did not acquire enough knowledge about the use of preventive measures before imprisonment, health professionals, especially nurses, should actively participate as facilitators in the teaching-learning processes in prison institutions. Therefore, through the public policies addressed at women, health professionals need to use individual and collective strategies in order to meet these clients in the attempt of ensuring their sexual and reproductive rights.

Knowledge about contraception can help individuals choose the method that better suits their sexual behavior and the correct way to use it considering the particularities that each presents. Thus, this knowledge will provide a healthy sexual and reproductive behavior, avoiding unwanted pregnancy, abortion and transmission of communicable diseases.

The availability of the female condom aims to increase the possibilities of prevention for women, although female prisoners did not mentioned this method, possibly due to their lack of knowledge, as well as the support from health professionals. This strengthens the idea that men determine the contraceptive method used in sex with their partners, reaffirming in women the lack of autonomy, the difficulty of negotiating and reducing their decision-making ability. A study conducted in a prison in São Paulo, Brazil, with 299 female inmates revealed that $95(60 \%)$ of these did not use condoms with men in the last year, and the other used it irregularly. None reported using regularly or in sexual practice with women [13].

The Manual on STD/AIDS states that civil society organizations should participate in and control actions in the access to services, in compliance with the pact to medicine procurement, in the education about the risks, provision of laboratory supplies, availability of condoms and other inputs. The use of condoms (male and female) for sexually active people is the most effective method for reducing the risk for HIV transmission and other sexually transmitted agents. It is the only method that provides double-protection, in other words, it effectively reduces the risk for HIV transmission and other STDs regarding contraception [14].

Nevertheless, the availability of condoms distributed by the public health system is not always sufficient to meet the needs of users. Thus, it is important to strengthen the idea of co-responsibility in supplying this resource for the care of sexual and reproductive health on the part of men and women.

The National Health Plan in the Prison System provides diagnostic actions, counseling and treatment for STD/HIV/AIDS, distribution of condoms to prisoners and servers, development of educational and instructional material, supply of specific medicines for HIV infection and other STDs, as well as actions for diagnosis and treatment of STDs depending on the strategy of the syndromic approach [1]. Many of these actions, however, still experience difficulties and institutional barriers.

We must consider that the female prisoners of the study reported having experienced situations of prostitution, which linked to vulnerability due to early onset of sexual activity, lack of knowledge, and not taking preventive measures, represents an additional risk factor for STD. The study of Viafore [15] included this practice as a component of the epidemiological representation of the female criminal figure. Many enter into prostitution in 
search of better financial conditions and become trapped in an illegal life, especially in drug trafficking, or yet as a means to support their addiction.

Women's involvements in the illicit trafficking in narcotic drugs are usually due to love connections with traffickers. Women are in subordinate positions in the trafficking schemes, such as "mules", which facilitates being arrested by the police and consequently being included in the criminal justice system [16].

Alcoholism seems to come from a social construction, that when properly conducted is acceptable by society, acting as a marker of social relations, social spaces, and body experience.

The use of alcohol and other drugs makes female inmates more vulnerable to unprotected sexual behaviors, facilitating infection by sexually transmitted diseases through inappropriate use, or non-use of condoms. A study reported that the main variables associated with STDs were infrequent condom use and consumption of legal and illegal drugs [17].

With regard to the offense, the study observed [18] that $41.1 \%$ of inmates admitted having committed the crime for which they are convicted for being under the influence of drugs (17.4\%) and alcohol (10.2\%). It also shows that $62.4 \%$ were involved in drug trafficking as subsidiary or subordinate function, although relevant to its purpose.

The issues concerning the abuse of alcohol and other drugs should be considered more broadly, without being restricted to the biological aspects, including also the social, educational, justice, development, and social spheres, because only then the policies for this problem will have an effective practice.

Regarding conjugal visit, this is a right violated in the institution studied, without proper hygiene of the cells where objects that should be of individual use are shared with other inmates. Without proper place to conjugal visits, the privacy of these women is inadequate and the provision of condoms, as well as instructions on its use and importance, does not happen regularly.

The fact that different couples use the area simultaneously for sexual intercourse, without the minimum hygiene, can facilitate the risk of STD/AIDS contamination.

It is worth highlighting that staying in Public Prisons restricts another right of female inmates, since conjugal visits are rarely allowed in these prisons, mainly due to the lack of adequate space [19].

Until the end of the 90s, there were no rules for conjugal visits for female prisoners, unlike for men, who always had this right guaranteed, justified by the belief that male sexual needs were greater, and for this reason should be met. National reports indicate gender inequality in relation to conjugal visits. They show that the right to visit does not reach incarcerated women at the same rate as men. The rights to conjugal visits for female prisoners are treated as mere liberality, not being guaranteed in most women's correctional facilities.

Nevertheless, in December 2001, the Department of Penitentiary Administration regulated the exercise of conjugal visits to women, ending almost two decades of violations of sexual and reproductive rights of female prisoners [20].

Although there are many stigmas and prejudices that fall on incarcerated people, except for the freedom and the right to vote for those already sentenced, they are entitled to the same rights and guarantees of the wider society, including sexual and reproductive rights that are recognizably human rights. This means that each person deprived of liberty has the right to conjugal visits, in which the management of the prison unit is responsible for such access, as provided for in specific legislation and regulations (see LEP/1984 and Resolution No. 09 of July 12, 2006) [21].

This assertion does not happen easily in the daily lives of these female prisoners, to the extent that the prisons, through laws and standards, provide this right, but not directly relates to the possibilities of occurrence of the event, in other words, to the choice of conjugal visits. This is justified by the existence of different orders of mediations present in the definitions and decisions of incarcerated women in achieving this right.

On the other hand, managers and health professionals are responsible for ensuring STD/AIDS prevention and promotion actions, with educational information, distribution of male and female condoms and intimate lubricants, contraceptive care, among others. Such actions should not be restricted to moments of conjugal visits, taking into account that these are not the only circumstances in which sexual relations exist within prisons. Furthermore, consensual sex is a right of people deprived of their liberty, without penalties and with the guarantee of access to condoms and contraception assistance [21].

\section{Conclusions}

These data comprised a situation of vulnerability facing a social exclusion to which this entire population was 
submitted before entering prison and that aggravated with imprisonment.

The qualitative data revealed important points for the implementation of strategies for this group: the fragility and inadequacy of information about sexually transmitted diseases and AIDS; low compliance in the use of contraception, especially condoms; the use of alcohol, tobacco, and illicit drugs; and no guarantee of the right to conjugal visits to these incarcerated women.

\section{References}

[1] Ministério da Saúde (2005) Departamento de ações programáticas estratégicas. Plano nacional de saúde no sistema penitenciário. 2 Ed, Ministério da Saúde, Brasília, Brasil.

[2] Presidência da República (2008) Secretaria Especial de Políticas para as Mulheres. Grupo de Trabalho Interministerial, Reorganização e Reformulação do Sistema Prisional Feminino, Presidência da República, Brasília, Secretaria Especial de Políticas para as Mulheres, Brasil.

[3] World Health Organization (2009) A mulher e o HIV em ambientes prisionais. WHO, Vienna.

[4] Gomes, R., Souza, E.R., Minayo, M.C.S. and Silva, C.F.R. (2005) organização, processamento, análise e interpretação de dados: o desafio da triangulação. In: Minayo, M.C.S., Assis, S.G., Souza, E.R., Org, Avaliação por triangulação de métodos: abordagem de programas sociais, Fiocruz, 185-221.

[5] Gomes, R (2009) Análise e interpretação de dados de pesquisa qualitativa. In: Minayo, M.C.S., Deslandes, S.F. and Gomes, R., Eds., Pesquisa social: Teoria, método e criatividade, 28ª Ed, Editora Vozes, Petrópolis, 79-108.

[6] Patton, M.Q. (2002) Qualitative Research and Evaluation Methods. 3rd Edition, Sage Publications, Thousand Oaks.

[7] Minayo, M.C. (2009) Trabalho de campo: Contexto de observação, interação e descoberta. In: Minayo, M.C.S. Deslandes, S.F. and Gomes, R., Eds., Pesquisa social: Teoria, método e criatividade. Editora Vozes, Petrópolis, 61-77.

[8] Conselho Nacional de Saúde, Brasil (2012) Resolução nº 466/12. Resolução 466, de 12 de dezembro de 2012. Estabelece critérios sobre pesquisa envolvendo seres humanos.

[9] Nicolau, A.I.O., Ribeiro, S.G., Lessa, P.R.A., Monte, A.S., Ferreira, R.C.N. and Pinheiro, A.K.B. (2012) A Picture of the Socioeconomic and Sexual Reality of Women Prisoners. Acta Paulista de Enfermagem, 25, 386-392. http://dx.doi.org/10.1590/S0103-21002012000300011

[10] Araújo, M.A.L. and Silveira, C.B. (2007) Vivências de mulheres com diagnóstico de Doença Sexualmente Transmissíveis-DST. Esc Anna Nery, 11, 479-486. http://dx.doi.org/10.1590/S1414-81452007000300013

[11] Nicolau, A.I.O., Ribeiro, S.S., Lessa, P.R.A., Monte, A.S., Bernardo, E.B.R. and Pinheiro, A.K.B. (2012) Knowledge, Attitude and Practices Regarding Condom Use among Women Prisoners: The Prevention of STD/HIV in the Prison Setting. Revista da Escola de Enfermagem da USP, 46, 711-719. http://dx.doi.org/10.1590/S0080-62342012000300025

[12] Nicolau, A.I.O. and Pinheiro, A.K.B. (2012) Condicionantes sociodemográficos e sexuais do conhecimento, atitude e prática de presidiárias quanto ao uso de preservativos. Texto \& Contexto Enfermagem, 21, 581-590.

[13] Strazza, L., Massad, E., Azevedo, R.S. and Carvalho, H.C. (2007) Estudo de comportamento associado à infecção pelo HIV e HCV em detentas de um presídio de São Paulo, Brasil. Cadernos de Saúde Pública, 23, 197-205. http://dx.doi.org/10.1590/S0102-311X2007000100021

[14] Brasil Departamento Penitenciário Nacional (2006) Sistema Penitenciário no Brasil Dados Consolidados. http://portal.mj.gov.br/depen/data/Pages/MJC4D50EDBPTBRNN.htm

[15] Viafore, D.A. (2005) Gravidez no cárcere brasileiro: Uma análise da Penitenciária Feminina Madre Pelletier. Direito \& Justiça, 31, 91-108.

[16] Oliveira, M.V.A. (2007) Criminalidade feminina: Um fenômeno em transformação. Diálogo Jurídico, 3, $203-218$.

[17] Codes, J.S., Cohen, D.A., Melo, N.A., Teixeira, G.G., Leal, A.S. and Silva, T.J. (2006) Detecção de doença sexualmente transmissíveis em ambientes clínicos e não clínicos na cidade de Salvador, Bahia, Brasil. Cad Saúde Pública, 22, 325-334. http://dx.doi.org/10.1590/S0102-311X2006000200010

[18] Lopes, R.M.F., Mello, D.C. and Argimon, I.I.L. (2010) Mulheres encarceradas e fatores associados a drogas e crimes. Ciênc Cognição, 15, 121-131.

[19] Ministério da Justiça (2007) Relatório Final, Grupo de Trabalho Interministerial. Reorganização e Reformulação do Sistema Prisional Feminino, Brasil.

[20] Dias, M.D., Filha, M.O.F. and Lima, G.M.B. (2005) Mulheres presidiárias: Sobreviventes de um mundo de sofrimento, desassistência e privações. Temas em Saúde (João Pessoa), 5, 44-48.

[21] Ministério da Saúde. Secretaria de Atenção em Saúde. Departamento de Ações Programáticas e Estratégicas (2010) Legislação da Saúde no Sistema Penitenciário. Ministério da Saúde, Brasília. 
Scientific Research Publishing (SCIRP) is one of the largest Open Access journal publishers. It is currently publishing more than 200 open access, online, peer-reviewed journals covering a wide range of academic disciplines. SCIRP serves the worldwide academic communities and contributes to the progress and application of science with its publication.

Other selected journals from SCIRP are listed as below. Submit your manuscript to us via either submit@scirp.org or Online Submission Portal.
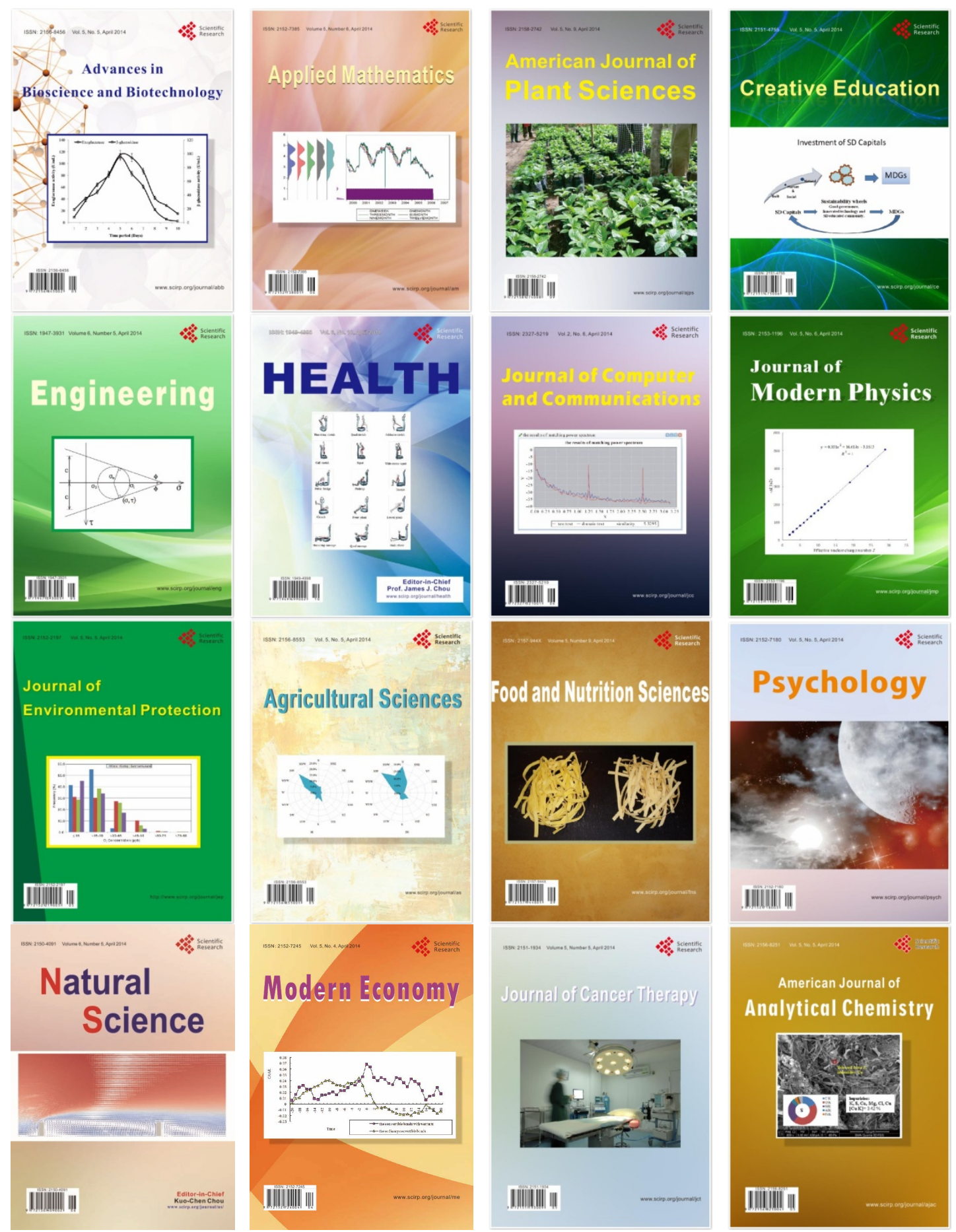